\title{
Continuous Biodegradation of Sugar Beet Distillery Stillage in an Aerobic Stirred-Tank Reactor: The Effect of Hydraulic Retention Time
}

\author{
Krzysztof Lutosławski*, Edmund Cibis, Małgorzata Krzywonos, \\ Agnieszka Ryznar-Luty
}

Department of Bioprocess Engineering, Wroclaw University of Economics and Business, Wrocław, Poland

Received: 1 March 2019

Accepted: 14 June 2019

\begin{abstract}
This study was aimed at examining the effect of hydraulic retention time (HRT) on the progress and efficiency of continuous biodegradation of sugar beet distillery stillage. Aerobic biodegradation of stillage was conducted in a 2-L stirred-tank reactor using a mixed culture of Bacillus bacteria under mesophilic conditions $\left(36^{\circ} \mathrm{C}\right)$. Continuous process was operated at HRTs of 39,58 and $90 \mathrm{~h}$. All experiments were performed at uncontrolled $\mathrm{pH}$, stirrer speed of $900 \mathrm{rpm}$, and aeration of $1.0 \mathrm{vvm}$. The $\mathrm{pH}$ value of degraded stillage (5.25) was also not adjusted. The longer the HRT, the higher the process efficiency expressed by the sum of chemical oxygen demand (COD) determined after suspended solids separation and theoretical COD of betaine, as well as by five-day biological oxygen demand and total organic carbon. The greatest reduction in these terms was achieved at HRT of 90 h, i.e., $80 \%, 98 \%$ and $73 \%$, respectively, at the COD removal rate of $0.3 \mathrm{~g} \mathrm{O}_{2} /(\mathrm{L} \mathrm{h})$. Only this variant of HRT ensured high assimilation of nitrogen (39\%) and total phosphorus (69\%) by bacteria. At the longest HRT, contents of reducing substances and organic acids decreased by $78 \%$ and $89 \%$, respectively, while glycerol and betaine were completely removed.
\end{abstract}

Keywords: aerobic continuous process, hydraulic retention time, stirred-tank reactor, sugar beet distillery stillage, wastewater biodegradation

\section{Introduction}

Next to sugar cane, sugar beets are one of the most popular sugar feedstocks intended for the production of ethanol, a popular biofuel [1]. However, manufacturers of sugar beet-based ethanol struggle with a serious

*e-mail: krzysztof.lutoslawski@ue.wroc.pl problem posed by the generated environmentally harmful wastewater named sugar beet distillery stillage. This is due to its high load of pollutants expressed as chemical oxygen demand (COD), five-day biological oxygen demand $\left(\mathrm{BOD}_{5}\right)$ and total organic carbon (TOC) [2], as well as to the high-volume ratio (12:1 L) of stillage to ethanol [3]. Currently, the annual production of ethanol generates nearly $12 \cdot 10^{9} \mathrm{~L}$ of sugar beet distillery stillage [4]. Considering the recent implementation of global programs which assume an 
increase in annual ethanol contribution to the market of liquid biofuels [1], the volume of stillage requiring disposal will increase proportionally.

The popularity of sugar beets as a raw material for ethanol production results from their short growing period, high resistance to temperature fluctuations, and low demands for water and fertilizers compared to, e.g., sugar cane [5]. Ethanol production from sugar beets has multiple advantages, including: no need for very expensive hydrolysis of the raw material [5], very high ethanol yield per 1 ha of crops (reaching even $8.5 \cdot 10^{3} \mathrm{~L}$ ) [6], and a high net energy value (the ratio of the energy provided by ethanol divided by energy required to produce that ethanol) of this ethanol (2.0) compared to maize-based ethanol (1.3) [7]. Finally, sugar beet-based ethanol combustion ensures a greater reduction of greenhouse gases (40-60\%) than combustion of ethanol made of starchy feedstocks $(15-20 \%)$ [8].

Perspectives for sugar beet-based bioethanol sector development on the market of biofuels also seem promising. A tropical sugar beet cultivar developed by Syngenta may be successfully cultivated (for ethanol production) in regions of the tropical and subtropical zones. Ethanol production from this cultivar has already been implemented in India and Colombia. Ethanol plants have also proven well in tests conducted in many other tropical regions of China, Australia, Kenya, South Africa, Brazil and the USA [9].

Currently, some research has been found about utilization of the effluent from sugar beet ethanol production. Sugar cane- or sugar beet-based stillage is usually treated as a fertilizer. However, fertilization has a negative impact on soil structure and water resources [10]. Another method of sugar beet-based stillage management, practiced mainly by the distillery industries of India, is to use it as a component in compost production [10]. In European ethanolproducing plants, a significant role in the management of sugar beet- or sugar cane-based stillage is ascribed to the anaerobic digestion which enables energy recovery as hydrogen and methane [11-13]. Valuable biogas is produced during anaerobic biodegradation most often in agri-distilleries coupled with sugar factories, like for example in France - being a tycoon in ethanol production from sugar beets, but also in the Czech Republic, Romania, and Spain [11]. However, treatment of sugar-based stillage alone during anaerobic digestion, without its additional supplementation with a carbon source or nutrients, is impossible [12]. In addition, the anaerobic fermentation process is conducted for the diluted stillage considering its high COD value and the many antimicrobial compounds it contains, including: 2,3-dimethylpyrazone, 2,2-bifuran5-carboxylic acid, 2-nitroacetophenone, 2,2-bifulan, 2-methylhexane, methylbenzene, 2,3-dihydro-5methylfuran, p-chloroanisole, 3-pyrroline, acetic acid etc. [10]. These compounds and also a low $\mathrm{pH}$ value of the stillage inhibit the anaerobic process by elongating the hydraulic retention time (HRT) [14]. As a result, in a single-stage anaerobic treatment of distillery wastewater, at HRT of typically 6-30 d and with organic loading rate (OLR) of 31-6.2 $\mathrm{g} \mathrm{O}_{2} /(\mathrm{L} \mathrm{d})$, COD reduction reaches $50-80 \%$, respectively. In turn, the maximum biogas production performance of $7.2 \mathrm{~m}^{3} /\left(\mathrm{m}^{3} \mathrm{~d}\right)(8 \mathrm{~d}$ HRT) and a maximum methane yield of $4.0 \mathrm{~m}^{3} /\left(\mathrm{m}^{3} \mathrm{~m}\right)$ (10 d HRT) are achieved at short HRTs [15].

Literature data indicates aerobic processes perceived by some authors as eco-friendly [10] - to be characterized by low sensitivity to a high contaminant load of distillery stillage [16]. Effective aerobic biodegradation of this effluent is usually achieved with a mixed culture of thermo- and mesophilic Bacillus bacteria [17, 18]. They have the ability to assimilate the main components of the stillage (betaine, reducing substances, organic acids, glycerol) [2] as well as coloured substances (alkaline products of invert sugar degradation, products of saccharose carmelization and melanoidins) [16, 19]. Moreover, Bacillus bacteria sp. were also characterized by high efficiency of degradation in other by-product of the agri-food industry, such as dairy $[20,21]$ or slaughter processing wastewater [22].

Nevertheless, stillage treatment only in the anaerobic or aerobic process does not allow for its final discharge into the natural environment. A very high treatment effect may be achieved by using various physical, chemical and/or biological treatment processes either alone or in combination [10]. For this reason, multi-stage processes (two- or three-stage), including the anaerobic-aerobic treatments, are used in the agridistilleries. For instance, in a full technical scale, Akarsubasi et al. [23] achieved COD removal of $90 \%$ in a two-stage treatment process conducted for distillery stillage, in which the first stage involved the anaerobic process and was followed by the aerobic process (activated sludge). In turn, Mota et al. [24] showed that COD reduction reaches $97 \%$ in a two-stage anaerobic membrane bioreactor during sugarcane vinasse treatment. In laboratory-scale research, Rodrigues et al. [25] in the multistage treatment process (coagulation followed by aerobic biodegradation and photo-Fenton oxidation) obtained 92,98 and $84 \%$ for COD, TOC and $\mathrm{BOD}_{5}$ removal, respectively.

Earlier research has proved batch processes of aerobic biodegradation of sugar based stillage by Bacillus bacteria promising, but showed their efficiency to depend on process conditions, including, e.g., $\mathrm{pH}$, temperature or dissolved oxygen tension $[18,26]$. To the best knowledge of the authors, no investigations have been undertaken to determine the effect of hydraulic retention time on the effectiveness of aerobic biodegradation of this effluent in continuous systems. Considering the above, the aim of this study was to examine the effect of various hydraulic retention times on continuous biodegradation of sugar beet distillery stillage by Bacillus bacteria culture in an aerobic stirred-tank reactor. 


\section{Material and Methods}

\section{Stillage}

The sugar beet distillery stillage came from the Manufacturing Trade Enterprise Rol-Mi-Go Ltd. (Jaśkowice Legnickie, Poland). The liquid phase of the stillage was treated. Filtrate was obtained with the use of a fluted filter paper (size $450 \times 560 \mathrm{~mm}$, grammage $65 \mathrm{~g} / \mathrm{m}^{2}$, Chempur, Poland). Before being used for analyses, the stillage was cooked for $15 \mathrm{~min}$ to eliminate microbiological contamination. The volume of liquid evaporated during cooking was filled with distilled water. The stillage was neither diluted nor supplemented with any additional biogens. The chemical composition of distillery stillage intended for biodegradation is presented in Table 1.

\section{Bacterial Culture}

The culture of Bacillus bacteria isolated in industrial plant processing wastes from the food industry was used in the study. It contained two strains from $B$. circulans species and one strain from each of the following species: B. laterosporus, B. filicolonicus, $B$. stearothermophilus, $B$. acidocaldarius, and $B$. licheniformis. The method for the diagnosis of bacterial strains was described in our previous work [16]. Before the bacterial culture had been used in the study, its activity was maintained in an aerobic bioreactor without mixing, having a working volume of $0.5 \mathrm{~L}$, aerated at the rate of $1.0 \mathrm{~L} /(\mathrm{L} \cdot \mathrm{min})$ and placed in an incubator at a temp. of $45 \pm 2^{\circ} \mathrm{C}$. Periodically, after 3 days of adaptation, the culture was inoculated onto fresh stillage medium $(0.5 \mathrm{~L})$, prepared according to the procedure described in the Stillage section. The initial $\mathrm{pH}$ value of the medium (adjusted using 33\% $\mathrm{NaOH}$ ) reached 7.5 and was not controlled during culture incubation. The volume of the inoculum used was $20 \mathrm{~mL}$. All biodegradation processes were performed with the inoculum from the above-mentioned $0.5 \mathrm{~L}$ - aerated bioreactor, which contained a three-day (after inoculation) bacterial culture.

\section{Process Setup}

Aerobic biodegradation of stillage was performed in a 2-L Biostat B fermenter of an STR (stirredtank reactor) type (B. Braun Biotech International) at uncontrolled $\mathrm{pH}$, stirrer speed of $900 \mathrm{rpm}$, aeration of $1.0 \mathrm{vvm}$ and under mesophilic conditions at $36^{\circ} \mathrm{C}$. This temperature was found to be optimal in our previous study with batch processes [2]. Continuous process was operated at consecutive HRT values of 39, 58 and $90 \mathrm{~h}$. The stillage was fed and removed from the reactor using peristaltic pumps (Vertex). The $\mathrm{pH}$ of stillage (5.25) fed continuously to the bioreactor was not adjusted. The volume of the medium during biodegradation was $1.62 \mathrm{~L}$. Prior to the start
Table 1. Chemical composition of sugar beet distillery stillage used in the experiments.

\begin{tabular}{|c|c|}
\hline Parameter $^{\mathrm{a}}$ & Value \\
\hline $\mathrm{pH}$ & $5.25 \pm 0.01$ \\
\hline Density $\left({ }^{\circ} \mathrm{Blg}\right)$ & $5.50 \pm 0.06$ \\
\hline Suspended solids (SS) (g/L) & $1.76 \pm 0.08$ \\
\hline COD (chemical oxygen demand) $\left(\mathrm{g} \mathrm{O}_{2} / \mathrm{L}\right)$ & $48.30 \pm 0.42$ \\
\hline $\mathrm{COD}_{\text {sum }}{ }^{\mathrm{b}}\left(\mathrm{g} \mathrm{O}_{2} / \mathrm{L}\right)$ & $50.10 \pm 0.47$ \\
\hline $\begin{array}{l}\mathrm{BOD}_{5} \text { (five-day biological oxygen demand) } \\
\qquad\left(\mathrm{g} \mathrm{O}_{2} / \mathrm{L}\right)\end{array}$ & $15.50 \pm 0.60$ \\
\hline TOC (total organic carbon) (g/L) & $13.02 \pm 0.54$ \\
\hline Reducing substances with hydrolysis (g/L) & $14.29 \pm 0.20$ \\
\hline Reducing substances without hydrolysis $(\mathrm{g} / \mathrm{L})$ & $5.38 \pm 0.05$ \\
\hline Sum of organic acids $(g / L)$ & $12.06 \pm 0.41$ \\
\hline Lactic acid $(\mathrm{g} / \mathrm{L})$ & $4.49 \pm 0.23$ \\
\hline Glycolic acid (g/L) & $2.52 \pm 0.13$ \\
\hline Acetic acid $(\mathrm{g} / \mathrm{L})$ & $1.29 \pm 0.07$ \\
\hline Pyroglutamic acid (g/L) & $1.12 \pm 0.05$ \\
\hline Isobutyric acid (g/L) & $0.92 \pm 0.06$ \\
\hline Butyric acid (g/L) & $0.83 \pm 0.03$ \\
\hline Formic acid (g/L) & $0.82 \pm 0.04$ \\
\hline Propionic acid (g/L) & $0.050 \pm 0.002$ \\
\hline Citric acid $(\mathrm{g} / \mathrm{L})$ & $0.010 \pm 0.001$ \\
\hline Tartaric acid (g/L) & $0.010 \pm 0.001$ \\
\hline Succinic acid $(\mathrm{g} / \mathrm{L})$ & $0.00 \pm 0.00$ \\
\hline Glycerol (g/L) & $3.08 \pm 0.06$ \\
\hline Betaine $(\mathrm{g} / \mathrm{L})$ & $0.86 \pm 0.06$ \\
\hline Total nitrogen $(\mathrm{g} / \mathrm{L})$ & $1.512 \pm 0.030$ \\
\hline Ammonia nitrogen $(\mathrm{g} / \mathrm{L})$ & $0.154 \pm 0.009$ \\
\hline Total phosphorus (g/L) & $0.290 \pm 0.004$ \\
\hline Phosphate phosphorus (g/L) & $0.199 \pm 0.002$ \\
\hline
\end{tabular}

Results are expressed as mean \pm standard deviation of the mean, $\mathrm{n}=3$.

${ }^{a}$ Besides $\mathrm{pH}$, density and suspended solids, the parameters were determined after suspended solids separation.

${ }^{\mathrm{b}}$ COD determined by the dichromate method + the theoretical COD of betaine.

of continuous experiments, a start-up batch process was performed in which the initial $\mathrm{pH}$ of the medium was 8.0. The first HRT $(39 \mathrm{~h})$ was set once $50 \%$ of the COD reduction had been exceeded in the start-up batch process. Other investigated values of the HRT parameter were set when the steady state was reached in the preceding continuous process. The steady state in the continuous processes was determined by the stabilization of all parameters, i.e., COD, 
the number of bacterial cells, and contents of suspended solids, reducing substances, organic acids, glycerol, total nitrogen, ammonia nitrogen, total phosphorus, and phosphate phosphorus.

\section{Analytical Methods}

The bacterial cell number $(\mathrm{BCN})$ was established using a hemocytometer (Thoma chamber, dimensions $0.05 \times 0.05 \times 0.1 \mathrm{~mm}$ ). To separate the suspended solids from the stillage, the sample was centrifuged in a Sigma4K15 centrifuge at a speed of 18,500 $\mathrm{g}$ for 40 min. After centrifuging, the content of suspended solids (SS) was determined in a $60-\mathrm{mL}$ sample with the gravimetric method [27]. The resultant supernatant was used for further analyses. The Hach-Lange cuvette tests were used for spectrophotometric measurements of chemical oxygen demand (COD), five-day biological oxygen demand $\left(\mathrm{BOD}_{5}\right)$, total organic carbon (TOC), total phosphorus and phosphate phosphorus [28]. Since COD determination with the dichromate method does not detect betaine, the $\mathrm{COD}_{\text {sum }}$ value was determined as the sum of the obtained COD value and the theoretical COD value of betaine (2.097 $\mathrm{g} \mathrm{O}_{2} / \mathrm{g}$ betaine). The organic loading rate (OLR) parameter was calculated as: [flow rate of stillage into the bioreactor $(\mathrm{L} / \mathrm{h})$ ] $\mathrm{x}$ $\left[\mathrm{COD}_{\text {sum }}\right.$ of stillage $\left.\left(\mathrm{g}_{2} \mathrm{O}_{2} / \mathrm{L}\right)\right]$ / [bioreactor volume (L)]. Organic acids were quantified with the HPLC method (chromatograph: Knauer; detectors: UV-VIS and RI; column: Phenomenex ROA Organic Acid - 7.8 $\mathrm{mm}$ i.d. $\mathrm{x} 300 \mathrm{~mm}$; eluent: $5 \mathrm{mM} \mathrm{H}_{2} \mathrm{SO}_{4}$; flow rate: $0.5 \mathrm{~mL} / \mathrm{min}$; temperature: $40^{\circ} \mathrm{C}$ ). The content of reducing substances was determined using the method of Lane-Eynon. Contents of glycerol and betaine were assayed spectrophotometrically [26]. Total nitrogen content was determined with Kjeldahl's method in C. Gerhardt GmbH \& Co. KG apparatus, whereas ammonia nitrogen content was with the distillation method using a Parnas apparatus [27]. The results were expressed as mean \pm standard deviation of the mean $(n=3)$. To analyze the mean effectiveness differences between two treatments, three steady-state samples were taken into account. Significant differences $(\mathrm{p} \leq 0.05)$ between the two groups were determined using the ANOVA test and Duncan's post hoc test.

\section{Results}

\section{Biodegradation Efficiency}

Hydraulic retention times (HRTs) of 39, 58 and 90 $h$ had a significant $(\mathrm{p} \leq 0.05)$ effect on the efficiency of continuous biodegradation of sugar beet distillery stillage in an aerobic stirred-tank reactor. The highest efficiency, expressed by the reduction of pollutant load indicators, i.e., $\mathrm{COD}_{\text {sum }}, \mathrm{BOD}_{5}$ and $\mathrm{TOC}$, was achieved at the longest HRT $(90 \mathrm{~h})$, and reached $80 \%, 98 \%$ and $73 \%$, respectively, in the steady state (Table 2). However, the longest HRT resulted also in the lowest $\mathrm{COD}_{\text {sum }}$ removal rate, which accounted for $0.3 \mathrm{~g} \mathrm{O}_{2} /(\mathrm{L} \mathrm{h})$ and in the lowest value of reactor load with $\mathrm{COD}_{\text {sum }}$ (OLR) reaching $0.4 \mathrm{~g} \mathrm{O}_{2} /(\mathrm{L} \mathrm{h})$ (Table 2). Biodegradation conducted at $39 \mathrm{~h}$ HRT increased both OLR and $\mathrm{COD}_{\text {sum }}$ removal rate by ca. 2.7-times, however it decreased biodegradation efficiency expressed as $\mathrm{COD}_{\text {sum }}$ removal. Finally, the $\mathrm{COD}_{\text {sum }}$ removal achieved under steady state at $39 \mathrm{~h}$ HRT was over $9 \%$ lower than at $90 \mathrm{~h}$ HRT (Table 2).

\section{Main Organic Compounds}

Elongation of the HRT from $39 \mathrm{~h}$ to $58 \mathrm{~h}$ enabled increasing the removal percentage of the main stillage

Table 2. Effect of hydraulic retention time (HRT) on the efficiency of continuous biodegradation of sugar beet distillery stillage in an aerobic stirred-tank reactor.

\begin{tabular}{|c|c|c|c|}
\hline \multirow{2}{*}{ Parameter } & \multicolumn{3}{|c|}{ Hydraulic retention time $(\mathrm{h})$} \\
\hline & 39 & 58 & 90 \\
\hline COD removal (\%) & $71.3 \pm 0.4$ & $76.3 \pm 0.5$ & $78.7 \pm 0.5$ \\
\hline $\mathrm{COD}_{\text {sum }}$ removal $(\%)$ & $70.5 \pm 0.4$ & $77.6^{\mathrm{a}} \pm 0.5$ & $79.6^{\mathrm{a}} \pm 0.5$ \\
\hline $\mathrm{BOD}_{5}$ removal $(\%)$ & $94.4^{b} \pm 0.6$ & $95.9^{\mathrm{b}} \pm 0.8$ & $98.1 \pm 0.2$ \\
\hline TOC removal $(\%)$ & $69.0^{c} \pm 1.4$ & $70.3^{\mathrm{c}} \pm 0.5$ & $72.9 \pm 0.6$ \\
\hline $\operatorname{OLR}\left(\mathrm{g} \mathrm{O}_{2} /(\mathrm{L} \mathrm{h})\right)$ & 1.1 & 0.7 & 0.4 \\
\hline $\mathrm{COD}_{\text {sum }}$ removal rate $\left(\mathrm{g} \mathrm{O}_{2} /(\mathrm{L} \mathrm{h})\right)$ & 0.8 & 0.5 & 0.3 \\
\hline Final number of cells $\left(10^{9} / \mathrm{mL}\right)$ & $5.5^{\mathrm{d}} \pm 0.3$ & $6.2^{\mathrm{d}} \pm 0.2$ & $7.5 \pm 0.4$ \\
\hline Final amount of SS formed (g/L) & $6.0^{\mathrm{e}} \pm 0.2$ & $6.1^{\mathrm{e}} \pm 0.1$ & $7.3 \pm 0.3$ \\
\hline $\mathrm{Y}_{\mathrm{SS}}\left(\left(\mathrm{g}\right.\right.$ final SS formed/g COD sum $_{\text {removed }) \cdot 100 \%)}$ & $20.5^{f} \pm 0.8$ & $19.8^{f} \pm 0.9$ & $25.7 \pm 1.1$ \\
\hline
\end{tabular}

Results are expressed as mean \pm standard deviation of the mean, $n=3$.

$\mathrm{a}, \mathrm{b}, \mathrm{c}, \mathrm{d}, \mathrm{e}, \mathrm{f}$ Differences in the values denoted by the same letter in the same row are statistically insignificant at $\mathrm{p} \leq 0.05$. 
Table 3. Effect of hydraulic retention time (HRT) on main organic compounds removal during continuous biodegradation of sugar beet distillery stillage in an aerobic stirred-tank reactor.

\begin{tabular}{|c|c|c|c|}
\hline \multirow{2}{*}{ Removal (\%) } & \multicolumn{3}{|c|}{ Hydraulic retention time $(\mathrm{h})$} \\
\hline & 39 & 58 & 90 \\
\hline Reducing substances with hydrolysis & $80.7^{\mathrm{a}} \pm 0.8$ & $83.0^{\mathrm{a}} \pm 0.4$ & $77.7 \pm 0.5$ \\
\hline Reducing substances without hydrolysis & $81.4 \pm 0.3$ & $82.4 \pm 0.3$ & $78.7 \pm 0.6$ \\
\hline Sum of organic acids & $66.5 \pm 0.8$ & $89.2^{b} \pm 0.3$ & $89.1^{\mathrm{b}} \pm 0.3$ \\
\hline Lactic acid & $100.0 \pm 0.0$ & $100.0 \pm 0.0$ & $100.0 \pm 0.0$ \\
\hline Glycolic acid & $96.4^{\mathrm{c}} \pm 0.2$ & $95.9^{\mathrm{c}} \pm 0.3$ & $100.0 \pm 0.0$ \\
\hline Acetic acid & $37.4^{\mathrm{d}} \pm 2.1$ & $28.2^{\mathrm{d}} \pm 2.0$ & $100.0 \pm 0.0$ \\
\hline Pyroglutamic acid & $72.2 \pm 1.7$ & $100.0 \pm 0.0$ & $100.0 \pm 0.0$ \\
\hline Isobutyric acid & $78.7 \pm 1.4$ & $32.8 \pm 4.4$ & $100.0 \pm 0.0$ \\
\hline Butyric acid & $-291.7 \pm 3.8$ & $91.6 \pm 0.2$ & $-89.2 \pm 2.3$ \\
\hline Formic acid & $99.5^{\mathrm{e}} \pm 0.1$ & $100.0 \pm 0.0$ & $99.6^{\mathrm{e}} \pm 0.0$ \\
\hline Propionic acid & $100.0 \pm 0.0$ & $100.0 \pm 0.0$ & $100.0 \pm 0.0$ \\
\hline Citric acid & $100.0 \pm 0.0$ & $100.0 \pm 0.0$ & $100.0 \pm 0.0$ \\
\hline Tartaric acid & $100.0 \pm 0.0$ & $100.0 \pm 0.0$ & $100.0 \pm 0.0$ \\
\hline Succinic acid & $100.0 \pm 0.0$ & $100.0 \pm 0.0$ & $100.0 \pm 0.0$ \\
\hline Glycerol & $100.0 \pm 0.0$ & $100.0 \pm 0.0$ & $100.0 \pm 0.0$ \\
\hline Betaine & $57.3 \pm 2.4$ & $100.0 \pm 0.0$ & $100.0 \pm 0.0$ \\
\hline Total nitrogen & $29.2^{ \pm} 1.2$ & $33.0 \pm 0.6$ & $38.9 \pm 1.6$ \\
\hline Ammonia nitrogen & $38.1 \pm 1.4$ & $45.3 \pm 1.2$ & $55.0 \pm 3.1$ \\
\hline Total phosphorus & $68.1^{\mathrm{f}} \pm 1.4$ & $80.0 \pm 1.3$ & $69.0^{\mathrm{f}} \pm 1.4$ \\
\hline Phosphate phosphorus & $74.0 \pm 0.9$ & $80.1^{\mathrm{g}} \pm 1.1$ & $83.6^{\mathrm{g}} \pm 0.8$ \\
\hline
\end{tabular}

Results are expressed as mean \pm standard deviation of the mean, $n=3$. The sign minus indicates an increase in the content of the pollutant.

$\mathrm{a}, \mathrm{b}, \mathrm{c}, \mathrm{d}, \mathrm{e}, \mathrm{f}, \mathrm{g}$ Differences in the values denoted by the same letter in the same row are statistically insignificant at $\mathrm{p} \leq 0.05$.

pollutants (Table 3). In addition, the removal of reducing substances from the stillage medium determined both after and before hydrolysis was higher in the process operated at $58 \mathrm{~h}$ HRT ( $83 \%$ and $82 \%$, respectively) than at $90 \mathrm{~h} \mathrm{HRT} \mathrm{(78 \%} \mathrm{and} \mathrm{79 \% ,} \mathrm{respectively).} \mathrm{Removal} \mathrm{of}$ organic acids in both these processes was similar and reached $89 \%$.

Regardless of hydraulic retention time, no glycerol was detected in the stillage medium during continuous biodegradation. In addition, at HRTs of 58 and 90 $\mathrm{h}$, also betaine was not detected in the medium (Table 3). While reducing substances and organic acids were determined in the stillage medium in all experiments, under both unsteady and steady states, (Fig. 1, Table 2).

At HRT of $39 \mathrm{~h}$, the total content of organic acids in the medium stabilized earlier (after ca. $135 \mathrm{~h}$ ) than that of reducing substances determined after hydrolysis (after ca. 159 h). An opposite observation was made during biodegradation conducted at 58 and $90 \mathrm{~h}$ HRT. Considering the course of changes in reducing substances, a steady state of their content was achieved at these HRTs after ca. 165 and $471 \mathrm{~h}$, whereas organic acids content stabilized after approximately 237 and 495 h, respectively (Fig. 1).

In the process operated at $39 \mathrm{~h}$ HRT, the significantly lower assimilation of organic acids was mainly due to the synthesis of butyric acid (Table 3 ). In the steady state, its content was nearly 3 -fold higher than in the stillage fed to the bioreactor (Table 3). The low percentage removal of the sum of organic acids under steady state of the process operated at $39 \mathrm{~h} \mathrm{HRT}$ was also attributed to the low removal percentage of acetic, pyroglutamic and isobutyric acids, accounting for $37 \%, 72 \%$ and $79 \%$, respectively, with the removal of the other assimilated organic acids exceeding 96\% (Table 3).

\section{Nitrogen and Phosphorus}

Results collated in Table 3 show greater assimilation of phosphorus among the assayed biogens. In each 


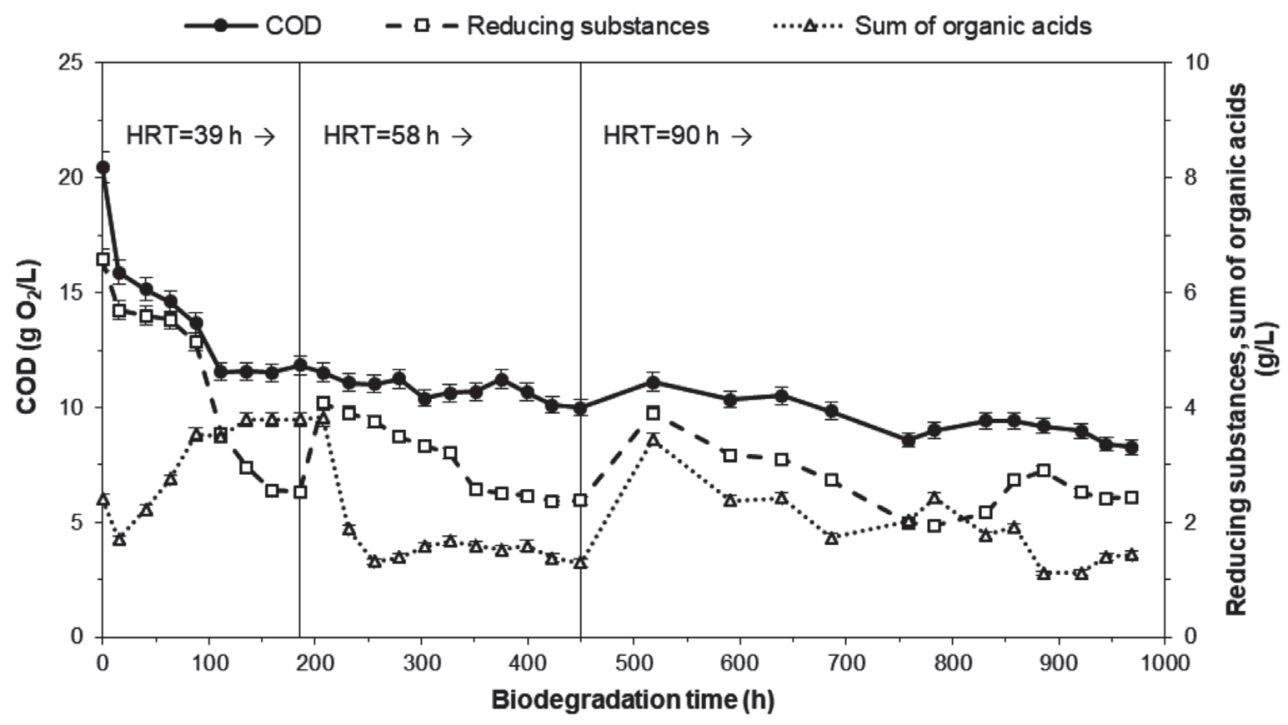

Fig. 1. Variations in COD, reducing substances with hydrolysis and sum of organic acids content during continuous biodegradation of sugar beet distillery stillage at HRT of 39, 58 and $90 \mathrm{~h}$.

process, the degree of assimilation of both total phosphorus and phosphate phosphorus by bacteria was high and fitted within the range of $68-80 \%$ and $74-$ $84 \%$, respectively. In turn, assimilation of total nitrogen and ammonia nitrogen did not exceed $39 \%$ and $55 \%$, respectively (Table 3). The assimilation of total- and ammonia nitrogen and also phosphate phosphorous increased along with a decreasing dilution rate. However, such a dependency was not confirmed in the case of total phosphorus removal, because at $90 \mathrm{~h}$ HRT, total phosphorus removal was lower by $11 \%$ than at $58 \mathrm{~h}$ HRT (Table 3).

During biodegradation conducted at $39 \mathrm{~h}$ HRT contents of both total nitrogen, ammonia nitrogen and total phosphorus stabilized in the $159 \mathrm{~h}$, whereas that of phosphate phosphorus as early as in the $64 \mathrm{~h}$ (Fig. 2). At $58 \mathrm{~h}$ HRT, contents of total nitrogen, total phosphorus and phosphate phosphorus in the medium stabilized in the $237 \mathrm{~h}$, and that of ammonia nitrogen - ca. $24 \mathrm{~h}$ earlier (Fig. 2). In the process conduced at $90 \mathrm{~h}$ HRT, contents of $\mathrm{N}$ and $\mathrm{P}$ stabilized in the $495 \mathrm{~h}$ (Fig. 2).

\section{Variations in $\mathrm{pH}$, DOT and Biomass}

Irrespective of the dilution rate, the least changes in the values of parameters determined in the unsteady state were observed for stillage medium $\mathrm{pH}$, which ranged from 8.2 to 8.8 in all experiments (Fig. 3). Hence, the low $\mathrm{pH}$ of the stillage fed to the reactor did not contribute to medium acidification during biodegradation. In contrast, the greatest changes occurred in biomass content (number of bacterial cells and content of suspended solids) in the medium (Fig. 3).

The process operated at the longest HRT $(90 \mathrm{~h})$ was characterized by a lesser demand for oxygen in the steady state compared to the other tested HRTs. In this process, dissolved oxygen tension in the medium stabilized at $91 \%$, whereas in processes conducted at $58 \mathrm{~h}$ and $39 \mathrm{~h}$ HRT the rates were 76 and $70 \%$, respectively (Fig. 3). Thus, it may be concluded that the longest tested HRT contributed to the lowest activity of the bacterial culture used for stillage biodegradation in the steady state, even though it was not the reason for the lowest bacterial cell number in a volume unit. Just the opposite, the longest HRT elicited the highest production of bacterial cells not only in the unsteady (Fig. 3) but also in the steady state (Table 2). This resulted also in the highest biomass production in the steady state. Values of the final number of cells and the final amount of SS formed achieved in this process accounted for $7.5 \cdot 10^{9} / \mathrm{mL}$ and $7.3 \mathrm{~g} / \mathrm{L}$, respectively (Table 2). Ultimately, the highest biomass content had a negative impact on the value of $Y_{S S}$ parameter, which at $90 \mathrm{~h}$ HRT was $5-6 \%$ higher than at the other HRTs (Table 2).

Variations in values of all determined kinetic parameters, presented in Figs 1-3 enable the conclusion that the steady state was reached faster in processes operated at the shorter hydraulic retention time. In the experiment conducted at $39 \mathrm{~h}$ HRT, the steady state was observed as soon as after ca. $159 \mathrm{~h}$ of biodegradation, whereas in the other experiments carried out at 58 h HRT and $90 \mathrm{~h}$ HRT were after ca. 237 and $495 \mathrm{~h}$, respectively (Figs 1-3). Hence, the number of reactor volume exchanges needed to reach the steady state ranged from ca. 4.0 ( $39 \mathrm{~h} \mathrm{HRT)} \mathrm{to} 5.5$ (90 h HRT). In each of the experiments, medium $\mathrm{pH}$ was the fastest stabilizing parameter (Fig. 3). At HRTs of 39, 58 and $90 \mathrm{~h}$, its value stabilized at $8.2,8.3$ and 8.4 after 94 , 172 and $404 \mathrm{~h}$, respectively. Values of the other parameters, like dissolved oxygen tension, bacterial cell number, and suspended solids content in the medium, were observed to stabilize much later (Fig. 3). 


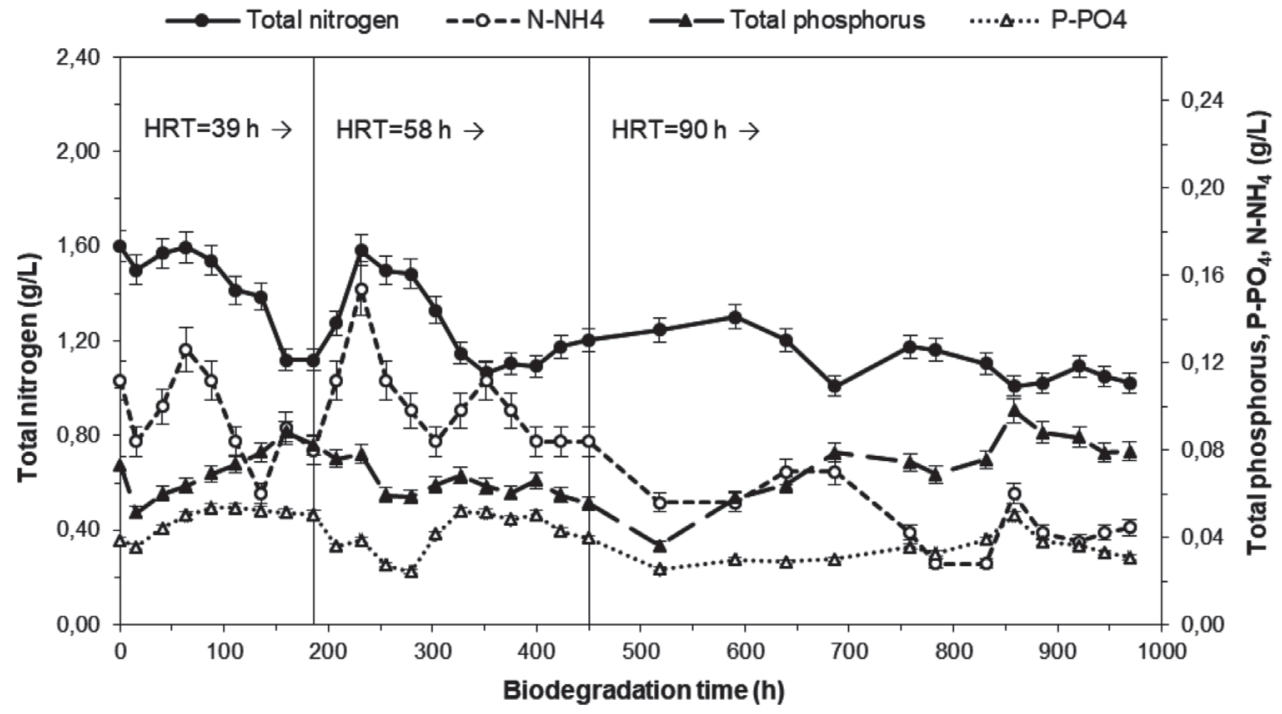

Fig. 2. Variations in nitrogen and phosphorus content during continuous biodegradation of sugar beet distillery stillage at HRT of 39,58 and $90 \mathrm{~h}$.

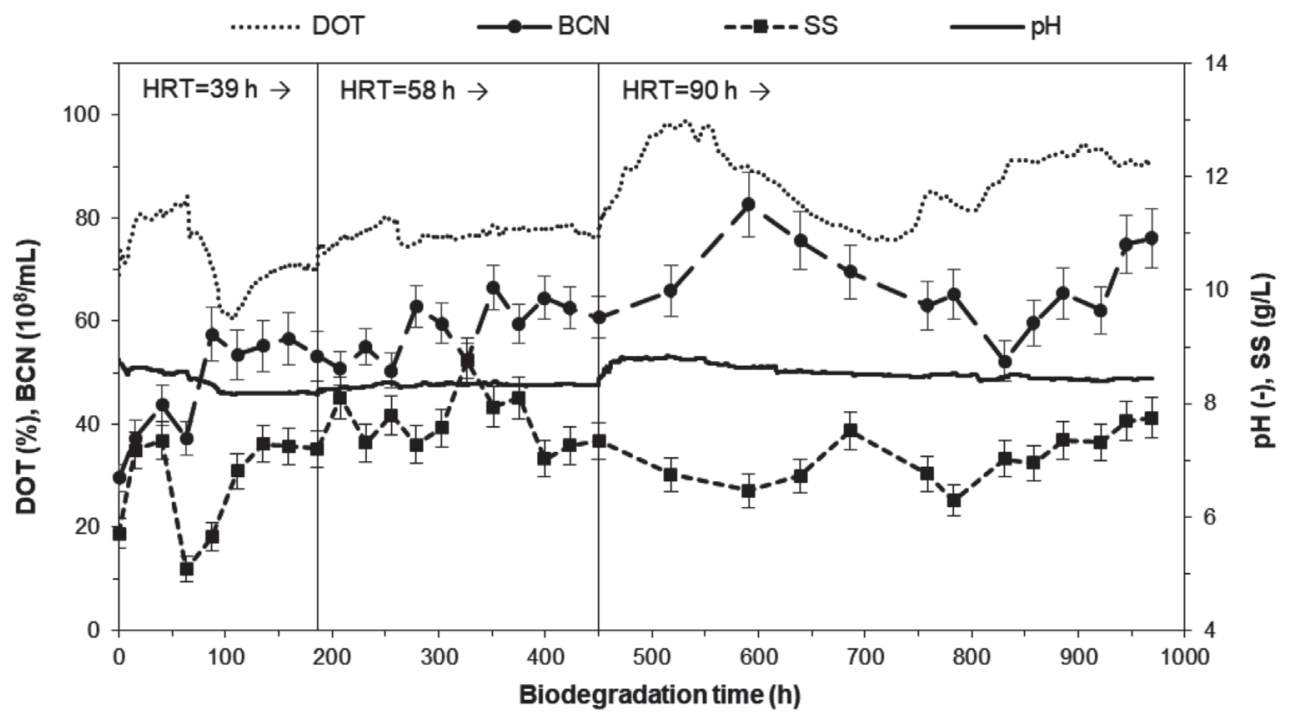

Fig. 3. Variations in $\mathrm{pH}$, dissolved oxygen tension (DOT), bacterial cell number (BCN) and suspended solids (SS) during continuous biodegradation of sugar beet distillery stillage at HRT of 39,58 and $90 \mathrm{~h}$.

\section{Discussion}

Obtained results confirm literature findings on the significant effect of the hydraulic retention time on biodegradation efficiency in continuous anaerobic or aerobic processes: an increasing efficiency of processes at elongated HRT was observed. A similar dependency was observed during single-stage anaerobic degradation of vinasse. An upflow anaerobic sludge blanket (UASB) reactor operated at similar HRT values to those tested in our experiment, i.e., from 36 to $72 \mathrm{~h}$, the achieved COD reduction ranged from 56 to $67 \%$, respectively [29]. However, the reduction values were lower than in our work. The mentioned dependency between the HRT and COD reduction was also observed during single-stage anaerobic biodegradation of distillery spent wash using different supplemented materials such as charcoal, coconut coir and nylon [15]. In a continuously fed up-flow fixed film column reactor under hydraulic retention time ranging from 144 to $720 \mathrm{~h}$, the reduction of contaminant load expressed as COD ranged from $50 \%$ to $80 \%$, respectively. It needs to be emphasized that we managed to achieve the same level of COD reduction $(80 \%)$ at a substantially shorter HRT, namely $90 \mathrm{~h}$. For this reason, our results of sugar beet distillery stillage treatment may be found to be more advantageous.

The highest COD removal achieved in this study may be deemed equally high, also in comparison to results of aerobic treatment of other high-strength 
effluents from the agri-food industry. A comparable extent of COD reduction was achieved in a continuous system for biodegradation of wastewater from the potato industry [30]. In a continuously stirred-tank reactor (CSTR) operated at different HRTs, the COD removal rates were between $76 \%$ at HRT of $12 \mathrm{~h}$ and $86 \%$ at HRT of $48 \mathrm{~h}$. Substantially worse outcomes of COD removal than in our study were reported in a work addressing bio-treatment of wastewater from the fat industry in a continuous system (15-20\%) [31]; however, low COD reduction efficiency was obtained by these authors at comparatively short hydraulic retention times of $6-50 \mathrm{~h}$.

Worthy of special attention is the fact that biodegradation of sugar beet distillery stillage conducted in the continuous mode did not deteriorate process efficiency obtained in the analogous batch process. Biodegradation of this stillage conducted in the batch system under the same conditions, comparable HRT and the same bacterial culture as in our study resulted in very similar reductions of $\mathrm{COD}, \mathrm{BOD}_{5}$ and TOC, accounting for $80 \%, 98 \%$ and $76 \%$, respectively, and in a similar value of the COD removal rate reaching $0.4 \mathrm{~g} \mathrm{O}_{2} /(\mathrm{L} \mathrm{h})$ [2]. Efficiency of the continuous process approximated efficiencies of other analogous batch processes of biodegradation of such distillery wastewaters like: sugar beet molasses vinasse [16, 26], corn stillage [32] and potato stillage [33]. The maximal COD reduction reported by these authors ranged from $74 \%$ (corn stillage) to $89 \%$ (potato stillage).

Also, organic load of the reactor (OLR) is an important parameter in the treatment technology developed for highly contaminated wastewater as it determines the efficiency of a continuous biodegradation process. In a series of three continuous experiments conducted in our study, the value of the OLR parameter ranged from 9.6 to $26.4 \mathrm{~g} \mathrm{O}_{2} /(\mathrm{L} \mathrm{d})$ with COD reduction ranging from $80 \%$ to $70 \%$, respectively (Table 2). Considering results reported for other wastewater with COD load, more similar to that of the sugar beet distillery stillage (not exceeding $77 \mathrm{~g} \mathrm{O}_{2} / \mathrm{L}$ ), the values of OLR and COD reduction achieved in this work may be found promising. For example, OLR values obtained upon aerobic biodegradation of oily wastewater under thermophilic conditions ranged from 2.7 [34] to $192 \mathrm{~g} \mathrm{O}_{2} /(\mathrm{L} \mathrm{d})$ [31], with COD reduction from $97 \%$ to $15 \%$, respectively. While Lasik and Nowak [35], who investigated the effect of dissolved oxygen tension in the medium on the efficiency of aerobic biodegradation of potato processing wastewater, reported OLR values in the range from 16 to $64 \mathrm{~g} \mathrm{O}_{2} /(\mathrm{L} \mathrm{d})$ with COD reduction from 60 to $25 \%$. In turn, OLR values obtained in single-stage anaerobic treatment of vinasse ranged from $3.4 \mathrm{~g} \mathrm{O}_{2} /(\mathrm{L} \mathrm{d})$ [36] to $31 \mathrm{~g} \mathrm{O}_{2} /(\mathrm{L} \mathrm{d})$ [15], with COD reduction in the range of 89 to $50 \%$, respectively.

The high removal of pollutants of the sugar beet distillery stillage, expressed by $\mathrm{COD}, \mathrm{BOD}_{5}$ and TOC indicators, was achieved due to the high capability of the mixed culture of bacteria from the genus Bacillus for degrading reducing substances, organic acids, glycerol and betaine, as well as nitrogen and phosphorus. Noteworthy is the fact that glycerol was completely assimilated from the stillage medium by bacteria in all experiments, namely irrespective of the hydraulic retention time. Also, complete degradation of betaine was observed when the reactor was operated at HRT of 58 or $90 \mathrm{~h}$ (Table 3). The total assimilation of betaine by bacteria was also observed during sugar beet molasses vinasse treatment [26], but glycerol degradation was not as efficient as in our experiment. Both reducing substances and organic acids were equally efficiently assimilated by bacteria from the genus Bacillus in the batch treatment of both sugar beet stillage [2] and sugar beet molasses vinasse [26].

Investigations conducted so far with both batch and continuous processes of distillery stillage biodegradation have demonstrated the highest rate of assimilation of glycerol, followed by reducing substances and organic acids by bacteria from the genus Bacillus [2]. As mentioned earlier, no glycerol was detected in the effluent from the reactor after biodegradation of sugar beet distillery stillage. It was very quickly assimilated by bacteria from the degraded medium in all experiments. In turn, the effluent from the reactor still contained reducing substances and organic acids. The processes operated at HRT of 58 and $90 \mathrm{~h}$ revealed faster stabilization of contents of reducing substances than of organic acids. An opposite observation was made in the third process ( $39 \mathrm{~h} \mathrm{HRT).}$ Stabilization of organic acids removal achieved later during biodegradation conducted at $90 \mathrm{~h}$ HRT was due to butyric acid synthesis (Table 3). Its synthesis was also observed during biodegradation of this stillage in batch processes [2], likewise, during continuous degradation processes of starch stillage from waste products and during batch processes of degradation of beet molasses vinasse [26]. It needs to be added that under certain process conditions, the Bacillus genus bacteria are also capable of synthesizing (in significant amounts) acetic, lactic, propionic, valeric, and formic acids [33]. As pinpointed by these authors, biosynthesis of organic acids usually intensifies at the stage of enhanced bacterial activity - namely at low dissolved oxygen tension in the medium.

Another important factor that determines the efficiency of treatment process is elimination of biogens from the wastewater. Their high contents in the wastewater directly discharged into the natural environment may lead to eutrophication. In the present study, the extent of total nitrogen and ammonia nitrogen removal in the steady state increased along with elongating hydraulic retention time. The reactor operating with HRT of $90 \mathrm{~h}$ allowed for achieving the maximum removal of total nitrogen, ammonia nitrogen and phosphate phosphorus from the degraded stillage, which accounted for 39, 55 and $84 \%$, respectively. Maximum removal of total phosphorous (80\%) was 
achieved at $58 \mathrm{~h}$ HRT. The high reduction in phosphorus content confirmed the high efficiency of its assimilation by aerobic microbes compared to anaerobic ones. Under anaerobic conditions, there is usually no significant decrease in phosphorus concentration in the distillery effluent [15].

The high biogens assimilation by used bacteria culture may be attributed to the appropriate process conditions. Previous studies have shown that the optimum temperature for removing both nitrogen and phosphorus from the sugar beet distillery stillage by the mixed culture of Bacillus bacteria is $36^{\circ} \mathrm{C}$. In the batch treatment system at this temperature, the decreases of $\mathrm{A}$ total and $\mathrm{P}$ total were $56 \%$ and $58 \%$, respectively [2]. Removal efficiency of these elements is also determined by the oxygen supply into the medium. Intensive mixing and aeration of the medium improves the bacterial assimilation of nitrogen as well as phosphorus from distillery effluents [18]. In the last cited work, the nitrogen content has been reduced by at least $20 \%$ higher in the STR processes than in the shake flask culture (SFC) and in the aerobic bioreactor without mixing (ABWM), while the phosphorus content has been reduced by $41 \%$ higher in the STR process than in the ABWM process. The maximum removal rates of total nitrogen and total phosphorus obtained in the STR experiments were $59 \%$ and $49 \%$, respectively. Worse results of nitrogen and phosphorus assimilation by Bacillus bacteria were achieved during treatment of wastewater generated in potato processing plants [37]. The reductions in total nitrogen and total phosphorus concentration did not exceed $22 \%$ and $29 \%$ respectively. Hence, the efficiency of $\mathrm{N}$ and $\mathrm{P}$ removal from the sugar beet distillery stillage presented in this paper may be found to be very satisfactory.

\section{Conclusions}

The continuous biodegradation of sugar beet distillery stillage in an aerobic stirred-tank reactor is characterized by a high efficiency. The longer is the HRT (or the lower is the dilution rate), the higher is the efficiency of stillage biodegradation indicated by reduced $\mathrm{COD}, \mathrm{BOD}_{5}$ and TOC values. At HRT of 90 $\mathrm{h}$, apart from the highest reduction of these indicators accounting for $80 \%, 98 \%$ and $73 \%$ respectively, analyses demonstrated the highest assimilation of total nitrogen $(39 \%)$ and high removal of total phosphorus $(69 \%)$ by the bacteria.

The proposed method of treatment proves effective for the sugar beet distillery stillage. However, considering the amount of pollutants remaining in the effluent after biodegradation (exceeding the limit for discharge into the environment), it should be treated as pre-treatment method. Thus, the continuous biodegradation process might become the first effective stage of the two- or multi-stage system for sugar beet distillery stillage treatment on the industrial scale.
Moreover, the continuous process could reduce the cost balance in agricultural distilleries, as it is unnecessary $\mathrm{pH}$ control of the treated stillage. The overall costs of the non-controlled $\mathrm{pH}$ processes are lower than controlled ones, mainly by the cost of $\mathrm{pH}$ neutralization agents and facilities requirements.

\section{Conflict of Interest}

The authors declare no conflict of interest.

\section{References}

1. REN21. Renewables Global Status Report, 2018. http:// www.ren21.net/status-of-renewables/global-status-report/ (accessed on 22 June 2018).

2. LUTOSŁAWSKI K., CIBIS E., KRZYWONOS M. The effect of temperature on the efficiency of aerobic biodegradation of sugar beet distillery stillage: Removal of pollution load and biogens. Braz. J. Chem. Eng., 34 (4), 985, 2017. doi:10.1590/0104-6632.20170344s20160417

3. GHOSH RAY S., GHANGREKAR M.M. Comprehensive review on treatment of high-strength distillery wastewater in advanced physico-chemical and biological degradation pathways. Int. J. Environ. Sci. Technol., 2018. doi:10.1007/ s13762-018-1786-8

4. FLACH B., LIEBERZ A., ROSSETTI A. EU Annual Biofuels Annual. USDA Foreign Agricultural Service, 2017. https:/gain.fas.usda.gov/ (accessed on 19 March 2018).

5. BALAT M., BALAT H., ÖZ C. Progress in bioethanol processing. Prog. Energy Combust. Sci., 34 (5), 551, 2008. doi:10.1016/j.pecs.2007.11.001

6. CIBE-CEFS. The EU beet and sugar sector: A model of environmental sustainability. International Confederation of European Beet Growers. Brussels, Belgium, 2010. https://www.agrana.com/fileadmin/inhalte/agrana_group/ downloads/EU_beet_an_sugar_sector_a_model_of environmental_sustainability.pdf (accessed on 22 April 2018).

7. BOWEN E., KENNEDY S.C., MIRANDA K. Ethanol from sugar beets: A process and economic analysis. Worcester Polytechnic Institute, 2010. https://web.wpi. edu/Pubs/E-project/Available/E-project-042810-165653/ (accessed on 12 February 2018).

8. TIMILSINA G.R., SHRESTHA A. Biofuels markets, targets and impacts. Policy Research Working Paper, 2010. doi:10.1596/1813-9450-5364

9. MARX S., BRANDLING J., GRYP P. Ethanol production from tropical sugar beet juice. Afr. J. Biotechnol., 11 (54), 11709, 2012. doi:10.5897/AJB12.1171

10. CHOWDHARY P., RAJ A., BHARAGAVA R. Environmental pollution and health hazards from distillery wastewater and treatment approaches to combat the environmental threats: A review. Chemosphere, 194, 229, 2018. doi:10.1016/j.chemosphere.2017.11.163

11. Tereos. Annual Report. Lille, France, 2014. https://tereos. com/en/ournews/2014-15-annual-report (accessed on 09 December 2017).

12. MORAES B., TRIOLO J., LECONA V., ZAIAT M., SOMMER S. Biogas production within the bioethanol production chain: Use of co-substrates for anaerobic 
digestion of sugar beet vinasse. Bioresour. Technol. 190, 227, 2015. doi:10.1016/j.biortech.2015.04.089

13. FERRAZ JÚNIOR A.D.N., KOYAMA M.H., ARAÚJO JÚNIOR M.M., ZAIAT M. Thermophilic anaerobic digestion of raw sugarcane vinasse. Renew. Energy, 89, 245, 2016. doi:10.1016/j.renene.2015.11.064

14. WAGH M.P., NEMADE P.D. Treatment processes and technologies for decolourization and COD removal of distillery spent wash: A review. Int. J. Innovative Res. Adv. Eng., 2 (7), 2349, 2015.

15. ACHARYA B.K., MOHANA S., MADAMWAR D. Anaerobic treatment of distillery spent wash - A study on upflow anaerobic fixed film bioreactor. Bioresour. Technol., 99 (11), 4621, 2008. doi:10.1016/j.biortech.2007.06.060

16. RYZNAR-LUTY A., CIBIS E., KRZYWONOS M., MIŚKIEWICZ T. Efficiency of aerobic biodegradation of beet molasses vinasse under non-controlled $\mathrm{pH}$ : conditions for betaine removal. Arch. Environ. Prot., 41 (1), 3, 2015. doi:10.1515/aep-2015-0001

17. RYZNAR-LUTY A., CIBIS E., LUTOSŁAWSKI K. Biodegradation of main carbon sources in vinasse stillage by a mixed culture of bacteria: influence of temperature and $\mathrm{pH}$ of the medium. Water Sci. Technol., 78 (4), 764, 2018. doi: $10.2166 /$ wst. 2018.342

18. LUTOSŁAWSKI K., RYZNAR-LUTY A., CIBIS E., KRZYWONOS M., MIŚKIEWICZ T. Biodegradation of beet molasses vinasse by a mixed culture of micro organisms: Effect of aeration conditions and $\mathrm{pH}$ control. J. Environ. Sci., 23 (11), 1823, 2011. doi:10.1016/s10010742(10)60579-7

19. WILK M., KRZYWONOS M., BOROWIAK D., SERUGA P. Decolourization of sugar beet molasses vinasse by lactic acid bacteria - the effect of yeast extract dosage. Pol. J. Environ. Stud., 28 (1), 385, 2018. doi.org/10.1007/s10479009-0669-2

20. PRIYADHARSHINI M., KUMAR R.S. Biodegradation of dairy wastewater using bacterial isolates. Int. J. Mod. Trends Eng. Sci., 3 (7), 133, 2016

21. LECH M., TRUSEK-HOLOWNIA A. Biodegradation of whey waste in a continuous stirred-tank bioreactor. Environ. Prot. Eng., 41 (4), 97, 2015. doi:10.5277/epe150408

22. LI W., JIA M.X., DENG J., WANG J.H., LIN Q.L., LIU C., WANG S.S., TANG J.X., ZENG X.X., MA L., SU W., LIU X.Y., CAI F., ZHOU L.Y. Isolation, genetic identification and degradation characteristics of COD-degrading bacterial strain in slaughter wastewater. Saudi J. Biol. Sci., 25 (8), 1800, 2018. doi.org/10.1016/j.sjbs.2018.08.022

23. AKARSUBASI A.T., INCE O., OZ N.A., KIRDAR B., INCE B.K. Evaluation of performance, acetoclastic methanogenic activity and archaeal composition of full-scale UASB reactors treating alcohol distillery wastewaters. Process Biochem., 41 (1), 28, 2006. doi:10.1016/j.procbio.2005.01.029

24. MOTA V., SANTOS F., AMARAL M. Two-stage anaerobic membrane bioreactor for the treatment of sugarcane vinasse: Assessment on biological activity and filtration performance. Bioresour. Technol., 146, 494, 2013. doi:10.1016/j.biortech.2013.07.110

25. RODRIGUES C., NETO A., DUDA R., OLIVEIRA R., BOAVENTURA R., MADEIRA L. Combination of chemical coagulation, photo-Fenton oxidation and biodegradation for the treatment of vinasse from sugar cane ethanol distillery. J. Clean Prod., 142, 3634, 2017. doi:10.1016/j.jclepro.2016.10.104

26. CIBIS E., RYZNAR-LUTY A., KRZYWONOS M., LUTOSŁAWSKI K., MIŚKIEWICZ T. Betaine removal during thermo- and mesophilic aerobic batch biodegradation of beet molasses vinasse: Influence of temperature and $\mathrm{pH}$ on the progress and efficiency of the process. J. Environ. Manage., 92 (7), 1733, 2011. doi:10.1016/j.jenvman.2011.02.009

27. RICE E., BAIRD R., EATON A. Standard Methods for the Examination of Water and Wastewater, 23rd ed.; American Public Health Association, American Water Works Association, Water Environment Federation. Washington DC, USA, 2017.

28. Water Analysis Handbook, $7^{\text {th }}$ edition; Hach Company. Loveland, Colorado, USA, 2012.

29. UTAMI I., REDJEKI S., ASTUTI D. H., SANI D. H. Biogas production and removal COD - BOD and TSS from wastewater industrial alcohol (vinasse) by modified UASB bioreactor. MATEC Web of Conferences, 58, 2016. doi.org/10.1051/matecconf $/ 20165801005$

30. MANHOKWE S., PARAWIRA W., ZVIDZAI C. Aerobic mesophilic treatment of potato industry wastewater. Int. J. Water Resour. Environ. Eng., 7 (7), 92, 2015. doi. org/10.5897/ijwree2015.0570

31. BECKER P., KÖSTER D., POPOV M.N., MARKOSSIAN S., ANTRANIKIAN G., MÄRKL H. The biodegradation of olive oil and the treatment of lipid-rich wool scouring wastewater under aerobic thermophilic conditions. Water Res., 33 (3), 653, 1999. doi:10.1016/s0043-1354(98)00253-x

32. RYZNAR-LUTY A., CIBIS E., LUTOSŁAWSKI K., KRZYWONOS M. Aerobic biodegradation of corn stillage in the STR bioreactor. Acta Sci. Pol. Biotechnol., 17 (2), 35, 2018 [In Polish]. doi: 10.30825/5.biot.56.2018.17.2

33. KRZYWONOS M., CIBIS E., LASIK M., NOWAK J., MIŚKIEWICZ T. Thermo- and mesophilic aerobic batch biodegradation of high-strength distillery wastewater (potato stillage) - Utilisation of main carbon sources. Bioresour. Technol., 100 (9), 2507, 2009. doi:10.1016/j. biortech.2008.12.008

34. HUNG J.M., CHEN C.Y., WU Y.S., LU C.J. Evaluation of specific biological heat potential of oily wastewater in an autothermal thermophilic aerobic treatment system. J. Environ. Biol., 29 (5), 655, 2008.

35. LASIK M., NOWAK J. Effect of pollution load and oxygen availability on thermophilic aerobic continuous biodegradation of potato processing wastewater. Eng. Life Sci., 7 (2), 187, 2007. doi:10.1002/elsc.200620181

36. MORAES B.S., ZAIAT M., BONOMI A. Anaerobic digestion of vinasse from sugarcane ethanol production in Brazil: Challenges and perspectives. Renewable Sustainable Energy Rev., 44, 888, 2015. doi.org/10.1016/j. rser.2015.01.023

37. LASIK M., NOWAK J., KRZYWONOS M., CIBIS E. Impact of batch, repeated-batch (with cell recycle and medium replacement) and continuous processes on the course and efficiency of aerobic thermophilic biodegradation of potato processing wastewater. Bioresour. Technol., 101 (10), 3444, 2010. doi:10.1016/j. biortech.2009.12.096 